\title{
Effect of temporal variation in precipitation on the demography of four herbaceous populations in a tropical dry forest area in Northeastern Brazil
}

\author{
Kleber Andrade da Silva ${ }^{1 *}$, Juliana Ramos de Andrade ${ }^{2}$, Josiene Maria Falcão Fraga dos Santos ${ }^{2}$, \\ Clarissa Gomes Reis Lopes ${ }^{3}$, Elba Maria Nogueira Ferraz ${ }^{4}$, Ulysses Paulino de Albuquerque ${ }^{2}$ \& \\ Elcida de Lima Araújo ${ }^{2}$ \\ 1. Centro Acadêmico de Vitória. Universidade Federal de Pernambuco. Bela Vista. C. P. 55608-680. Brazil. Vitória de \\ Santo Antão, Pernambuco; kleberandradedasilva@hotmail.com \\ 2. Departamento de Biologia. Universidade Federal Rural de Pernambuco. Dois Irmãos. C. P. 52171-900. Brazil. Recife, \\ Pernambuco; jubinha1791@hotmail.com, enefalcaoo@hotmail.com, upa@db.ufrpe.br, elcida@db.ufrpe.br \\ 3. Campus Amílcar Ferreira Sobral. Universidade Federal do Piauí. Meladão. C. P. 64800-000. Brazil. Floriano, Piauí; \\ claris-lopes@hotmail.com \\ 4. Instituto Federal de Educação, Ciência e Tecnologia de Pernambuco. Cidade Universitária. C. P. 50740-540. Brazil. \\ Recife, Pernambuco; elbanogueira@superig.com.br \\ * Correspondence
}

Received 20-X-2014. Corrected 20-V-2015. Accepted 26-VI-2015.

\begin{abstract}
In tropical dry forests, the dynamics of herbaceous populations is strongly influenced by seasonal and annual variation in total rainfall. Moreover, the present and past events of climatic anomalies (e.g. severe drought years and erratic rain before the growth season) may cause drastic reductions in population size, leading to the temporal disappearance of some species. Therefore, this three-year study aimed to assess the dynamics of Delilia biflora (Asteraceae), Commelina obliqua (Commelinaceae), Phaseolus peduncularis (Fabaceae) and Euphorbia heterophylla (Euphorbiaceae). The study was conducted in an area of tropical dry forest known as Caatinga, situated in the experimental station of the Pernambuco Agronomic Institute (IPA), in Caruaru, Pernambuco, Brazil. The Caatinga has a semiarid climate with strong seasonal and annual variation in total precipitation. During this study, there was a climatic anomaly event called the 2006 drought, and also erratic rains in the dry season. The birth, death and survival of plants were evaluated monthly using 105 plots $(1 \times 1 \mathrm{~m})$. Differences in density between years and seasons were evaluated using the Kruskal-Wallis test. The explanatory power of present and past precipitation on density was evaluated using the General Linear Model. In this study, we present the first record of Euphorbia heterophylla in the studied area. The studied populations were larger during the rainy seasons and in wet years, and were drastically reduced in the driest year and dry seasons. Commelina obliqua was the least sensitive to variation in total rainfall. Regarding the variation in density, all four species were present during all three years. Birth rates were higher during the rainy season, and death rates were higher in the dry season. Sporadic rain in the dry season caused pronounced seedling recruitment followed by death, and had a strong impact on the dynamics of D. biflora, E. heterophylla and P. peduncularis. The precipitation of the current year explained between $3 \%-18 \%$ of the inter-annual density variation, and the explanatory power of the previous year precipitation on the density of populations ranged from $32 \%$ to $67 \%$. Therefore, climatic events of the past also have a significant consequence over the four populations. In conclusion, drastic reduction in total precipitation between years may be considered as a predictive parameter for herbaceous plants population size (in the present and future time) in a Northeastern Brazilian tropical dry forest area. Rev. Biol. Trop. 63 (4): 903-914. Epub 2015 December 01.
\end{abstract}

Key words: Caatinga, density, dynamics, rainfall, seedling recruitment, semi-arid. 
Dry tropical forests occur in extense areas of the Americas, Africa, Asia and Australia (Khurana \& Singh, 2001; Vieira \& Scariot, 2006). In these forests, total rainfall variations between climatic seasons and between years have been cited as predictors of productivity, regarding density, biomass and seed production of herbaceous plants. According to the literature, there is a positive and significant correlation between productivity of herbs and total annual rainfall in desert areas of USA (Salo, 2004), Mexico (Vega \& Montaña, 2004), Israel (Volis, Mendlinger, \& Ward, 2004), China (Wang, 2005), African Savannah (Belsky, 1990), Brazilian Caatinga (Silva et al., 2008) and Semiarid Scrubland (García-Cháves, Montaña, Perroni, Sosa, \& García-Licona, 2014). However, some herbaceous species may not fit this pattern (Nippert, Knapp, \& Briggs, 2006; Lima et al., 2007; Silva et al., 2008). Nippert et al. (2006) observed that rainfall and soil moisture are positively and significantly correlated to grass productivity in Northeastern Kansas, USA; however, there is no significant correlation for dicotyledonous herbs, suggesting the existence of other factors that influence the productivity of this group.

Usually, within a year, the herbs that occur in dry tropical forests form larger populations during the period known as the growth season, because temperature and moisture conditions are favorable for the recruitment, establishment and survival of seedlings. On the other hand, during the period known as the unfavorable period, the populations may show a dramatic or moderate reduction in size or may remain stable. In the case of herbs with an annual life cycle, individuals die and species remain in the area in the form of seeds (Andrade et al., 2007; Santos, Andrade, Lima, Silva, \& Araújo, 2007; Santos et al., 2013a).

In some areas, climate anomaly of erratic rains before the growth season causes seed germination and the emergence of seedlings, but the subsequent drought results in mortality before individuals can reach the reproductive stage. Consequently, there may be a reduction in seeds production during that season (Salo,
2004; Silva et al., 2008; Villalobos, Poorter, \& Martínez-Ramos, 2013), which may compromise the size of populations in the subsequent year. An example of such reduction is observed in an annual grass, Bromus madritensis subsp. rubens (L.) Duvin (Poaceae), found in arid areas in Southern and Southeastern USA (Salo, 2004). In a dry tropical forest area in Northeastern Brazil, the mortality rate of seedlings, recruited during the occurrence of sporadic rain in the dry period is also high (Lima et al., 2007; Silva et al., 2008). Moreover, anomalous dry years may cause drastic reductions in herbaceous population size, leading to the temporal disappearance of some species from the community (Reis, Araújo, Ferraz, \& Moura, 2006; Miriti, Rodríguez-Buritica, Wright, \& Howe, 2007).

In the Northeastern region of Brazil, dry tropical forests are well known for their vegetation, known as Caatinga (Prado, 2003; Araújo, Castro, \& Albuquerque, 2007). The Caatinga has a semi-arid climate and strong seasonal and annual variation in total precipitation (Sampaio, 1995; Araújo et al., 2007). The families with the largest number of species are Poaceae (e.g. Panicum trichoides), Fabaceae (e.g. Desmodium glabrum), Malvaceae (e.g. Physaloides stoloniferum) and Euphorbiaceae (e.g. Euphorbia insulana) (Araújo, Silva, Ferraz, Sampaio, \& Silva, 2005; Reis et al., 2006). In the Caatinga, herbaceous species richness can be three times higher than that of woody species (Araújo et al., 2007). The impact of total rainfall variations on herbaceous populations of Caatinga has been the focus of a number of studies (Andrade et al., 2007; Lima et al., 2007; Santos et al., 2007; Silva et al., 2008), the findings of which indicate that the herbs are sensitive to climate variations in terms of both phenological behavior of the plants and population dynamics. However, the nature of the relationship between total rainfall (including events of climatic anomaly) and demographic characteristics of the populations has not yet been assessed.

Therefore, based on the premise that the seasonal and annual variations in total rainfall 
may model the size of herb populations of dry tropical forests worldwide, the hypothesis of this study is that the reduction in herbaceous populations that occur in the Caatinga is related to the reduction in total rainfall and the present and past events of climatic anomalies can reduce herbaceous populations size. Thus, the objective of this study was to evaluate the seasonal and annual influence of total rainfall on density, recruitment, mortality and survival of four herbaceous species from the Caatinga. Whereas this study was conducted during an event of climatic anomalies (i.e. the 2006 drought and erratic rain in dry season), we also questioned whether this event had consequences over the demography even of the herb species adapted to the drought environment the Caatinga.

\section{MATERIALS AND METHODS}

Study area: The study was conducted in an area of tropical dry forest known as Caatinga, situated in the experimental station of the Pernambuco's Agronomic Institute, or IPA (8'14'18" S - 35055'20" W, 535 masl), in Caruaru, Pernambuco, Brazil (Fig. 1). The IPA encompasses a stretch of native vegetation where neither the development of human activities nor the trafficking of animals for pasture is permitted. This stretch was designated to preserve (for at least 50 years), whereas other areas of the IPA function as experimental stations.

The floristic composition of the woody and herbaceous vegetation of this stretch was studied by Alcoforado-Filho, Sampaio and Rodal (2003), Araújo et al. (2005), Lucena, Nascimento, Araújo and Albuquerque (2008) and Reis et al. (2006). These studies showed that the woody component of the area displays a high richness of Leguminosae and Euphorbiaceae species. It also showed that the herbaceous component presented a high richness of species belonging to Malvaceae, Poaceae, Asteraceae, Euphorbiaceae and Convolvulaceae families. However, according to Reis et al. (2006), not all herbs present in the stretch occur every year in that area, resulting in a permanent herbaceous flora, as well as a transitory component in the Caatinga vegetation.

The climate is seasonal, with average annual rainfall of $680 \mathrm{~mm}$ and absolute minimum and maximum temperatures of $11{ }^{\circ} \mathrm{C}$ and $38^{\circ} \mathrm{C}$, respectively. The rainy season usually occurs between March and August, although droughts may occur in the rainy season, and erratic rains may occur in the dry season. However, there is a high variation in total rainfall and in the length of the rainy season from year to year, as observed during this threeyear study. The rainy season was anticipated

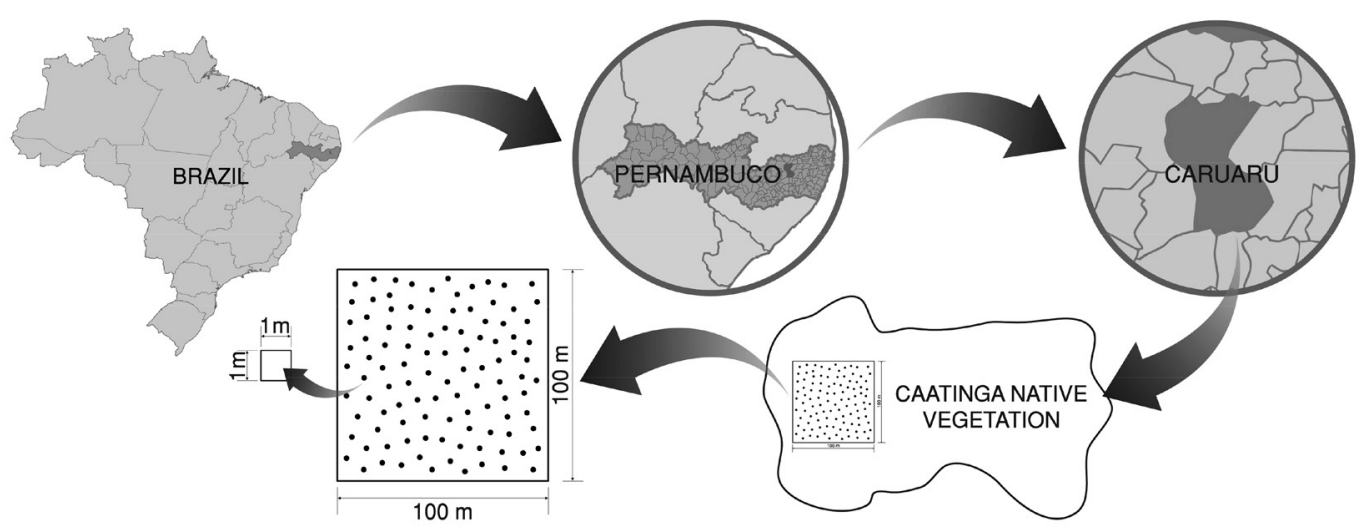

Fig. 1. Distribution of parcels in the study areas at the Pernambuco Agronomic Institute (IPA) - Caruaru, Pernambuco, Brazil. 
in 2006, beginning in February, and the 2007 rainy season persisted until September. Erratic rains were recorded in December 2005 and in January 2008 (Fig. 2). The soil is an Eutrophic Yellow Podzol, and the area is drained by the Olaria Stream, a tributary of the Ipojuca River (Alcoforado-Filho et al., 2003; Silva et al., 2008; Monteiro, Lins Neto, Araújo, Amorim, \& Albuquerque, 2011).

Selected species: The species that were selected for this study were the therophytes Delilia biflora (L.) Kuntze (Asteraceae), Commelina obliqua Vahl (Commelinaceae) and Phaseolus peduncularis W.P.C. Barton (Fabaceae), which form abundant populations in the area and are part of the permanent herbaceous flora (Araújo et al., 2005; Reis et al., 2006). The therophyte Euphorbia heterophylla (L.) Klotzsch and Garcke (Euphorbiaceae), which was not recorded by Araújo et al. (2005) and Reis et al. (2006), is probably part of the transitory flora. The four species are native, non-endemic and are distributed in native and disturbed areas. The herbaceous component plays an important role in the maintenance and restoration of biodiversity beeing a source of food for animals, and assisting in the retention of seeds on the soil surface. Beyond that, many species are used in the treatment of diseases.
Sampling of populations: In the native vegetation stretch, 105 plots $(1 \times 1 \mathrm{~m})$ were randomly demarcated (Fig. 1). The randomization was based on pre-existing, permanently marked $5 \times 5 \mathrm{~m}$ plots. The $5 \times 5 \mathrm{~m}$ grids were divided into smaller ones, measuring $1 \times 1$ $\mathrm{m}$, from which the plots for this study were selected (Araújo et al., 2005). Inside the plots, all the individuals from the four species were counted and marked with plastic tags, attached to the individuals with plastic-coated wires. Each plant that did not exhibit a connection with any other plant at soil level, was considered an individual. The plots were evaluated monthly in order to record the numbers of plants germinated and deaths. Every individual exhibiting complete loss of the aboveground portion, or has became completely dry on the soil, was considered dead. The study was conducted from March 2005 to March 2008 and was divided into three periods (the first of 11 months, the second of 12 months and the third of 13 months), each with a rainy and a dry season, for a total of three years of monitoring (Fig. 2).

Data processing and analysis: Herbarium specimens were made, according to the standard techniques of preparation, drying and assembling of exsiccates (Mori, Silva, \&

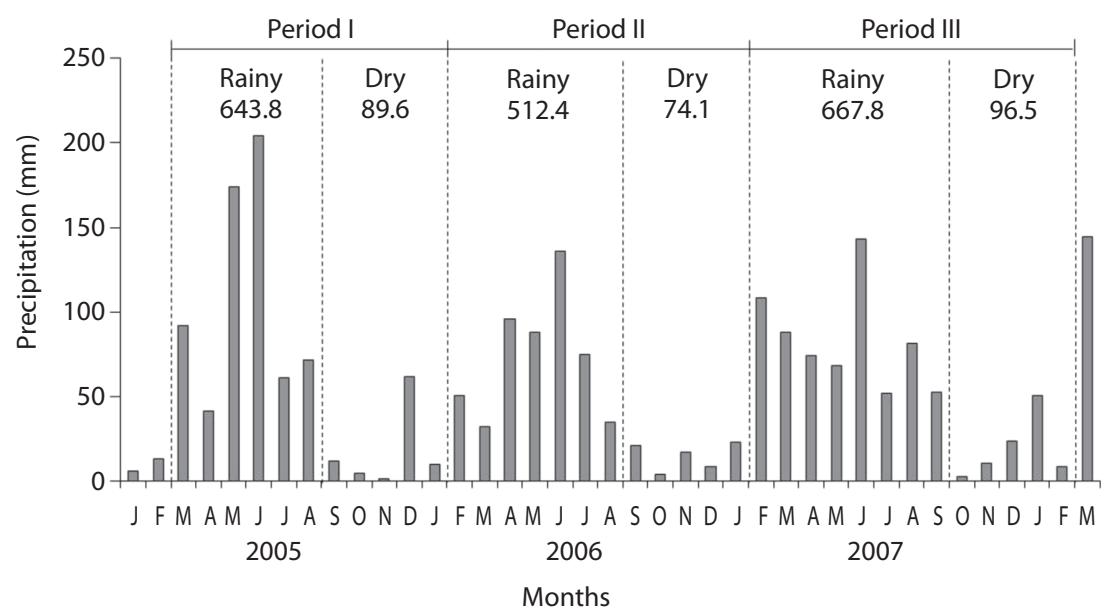

Fig. 2. Monthly precipitation and total precipitation during the rainy and dry season for three years. Data provided by the meteorological station of Pernambuco Agronomic Institute (IPA) - Caruaru, Pernambuco, Brazil. 
Lisboa, 1989). Taxonomic identification was made by a specialist and, through comparison with exsiccates deposited in the Prof. Vasconcelos Sobrinho Herbarium (PEUFR) at the Pernambuco Federal Rural University and Dárdano de Andrade Lima Herbarium at the Pernambuco Agronomic Institute (IPA). Botanical material collected was incorporated into the PEUFR herbarium (voucher number: Delilia biflora - 43 329; Phaseolus peduncularis - 47 387; Commelina obliqua - 43 355; Euphorbia heterophylla 43 367).

The natality $(b$, number of plants germinated in a given month) and mortality ( $d$, number of deaths in a given month) rates were calculated using the following equations: (1) $d=\ln \left(\mathrm{N}_{0} /\left(\mathrm{N}_{0}-\mathrm{D}\right)\right) / \mathrm{T}$; and (2) $b=\ln \left(\mathrm{N}_{0}\right.$ / $\left.\left(\mathrm{N}_{0}-\mathrm{B}\right)\right)$ / T; where $N_{0}$ corresponds to the number of individuals from the initial census; $B$ corresponds to the number of individuals that were born in the interval between two subsequent observations; $D$ corresponds to the number of individuals that died in the interval between two subsequent observations and $\mathrm{T}$ is time (number of days between two subsequent observations) (Swaine, \& Lieberman, 1987; Condit, Hubbell, \& Foster, 1996). Differences in density between periods and seasons were evaluated using the Kruskal-Wallis test (Zar, 1996). The analysis was conducted with the BioEstat 5.0 software (Ayres, Ayres-júnior, Ayres, \& Santos, 2007). The explanatory power of present and past precipitation $(\mathrm{mm})$ over the density of herbaceous populations was evaluated using the General Linear Model (GLM) (Zar, 1996). We used the GLM because there was no correlation between mean and variance.

\section{RESULTS}

Density: In this study, it was recorded for the first time the presence of Euphorbia heterophylla in the studied area. The annual precipitation recorded for the year before the start of this study (2004) was of $1064.3 \mathrm{~mm}$. In this study, there was an event of climatic anomaly called the 2006 drought because the precipitation reduced about $50 \%$ (586 mm). This event of climatic anomaly had demographic consequences over herbaceous populations. In the second and third periods, there was a dramatic reduction in the population sizes of the four studied species when compared to the size of the same populations in the first period (Fig. 3; Table 1). However, none of the populations disappeared completely (Fig. 3), despite being

TABLE 1

Densities mean $\left(105 \mathrm{~m}^{2}\right)$ and standard deviations of four herbaceous populations in a tropical dry forest area (Caatinga) in Northeastern Brazil

\begin{tabular}{lcccc}
\multicolumn{1}{c}{ Species } & Periods & Rainy season & Dry season & Total \\
Delilia biflora & I & $8262 \pm 1339 \mathrm{aA}$ & $3225 \pm 1587 \mathrm{bA}$ & $6018 \pm 2924 \mathrm{~A}$ \\
& II & $334 \pm 68 \mathrm{aC}$ & $148 \pm 39 \mathrm{bB}$ & $256 \pm 111 \mathrm{~B}$ \\
Commelina obliqua & III & $580 \pm 160 \mathrm{aB}$ & $271 \pm 129 \mathrm{bB}$ & $461 \pm 212 \mathrm{~B}$ \\
& I & $124 \pm 21 \mathrm{aA}$ & $79 \pm 23 \mathrm{bA}$ & $104 \pm 31 \mathrm{~A}$ \\
Euphorbia heterophylla & II & $77 \pm 14 \mathrm{aB}$ & $51 \pm 15 \mathrm{bB}$ & $66 \pm 19 \mathrm{~B}$ \\
& III & $80 \pm 9 \mathrm{aB}$ & $45 \pm 6 \mathrm{bB}$ & $66 \pm 19 \mathrm{~B}$ \\
& I & $158 \pm 29 \mathrm{aA}$ & $72 \pm 39 \mathrm{bA}$ & $119 \pm 55 \mathrm{~A}$ \\
Phaseolus peduncularis & II & $21 \pm 3 \mathrm{aC}$ & $9 \pm 5 \mathrm{bB}$ & $16 \pm 7 \mathrm{C}$ \\
& III & $55 \pm 21 \mathrm{aB}$ & $20 \pm 4 \mathrm{bB}$ & $42 \pm 24 \mathrm{~B}$ \\
& I & $2092 \pm 255 \mathrm{aA}$ & $1010 \pm 308 \mathrm{bA}$ & $1600 \pm 624 \mathrm{~A}$ \\
\hline
\end{tabular}

The same lower case letters in a line and the same capital letters in a column indicate a lack of significant differences $(\mathrm{P}<$ $0.05)$, based on the Kruskal-Wallis analysis of variance. 


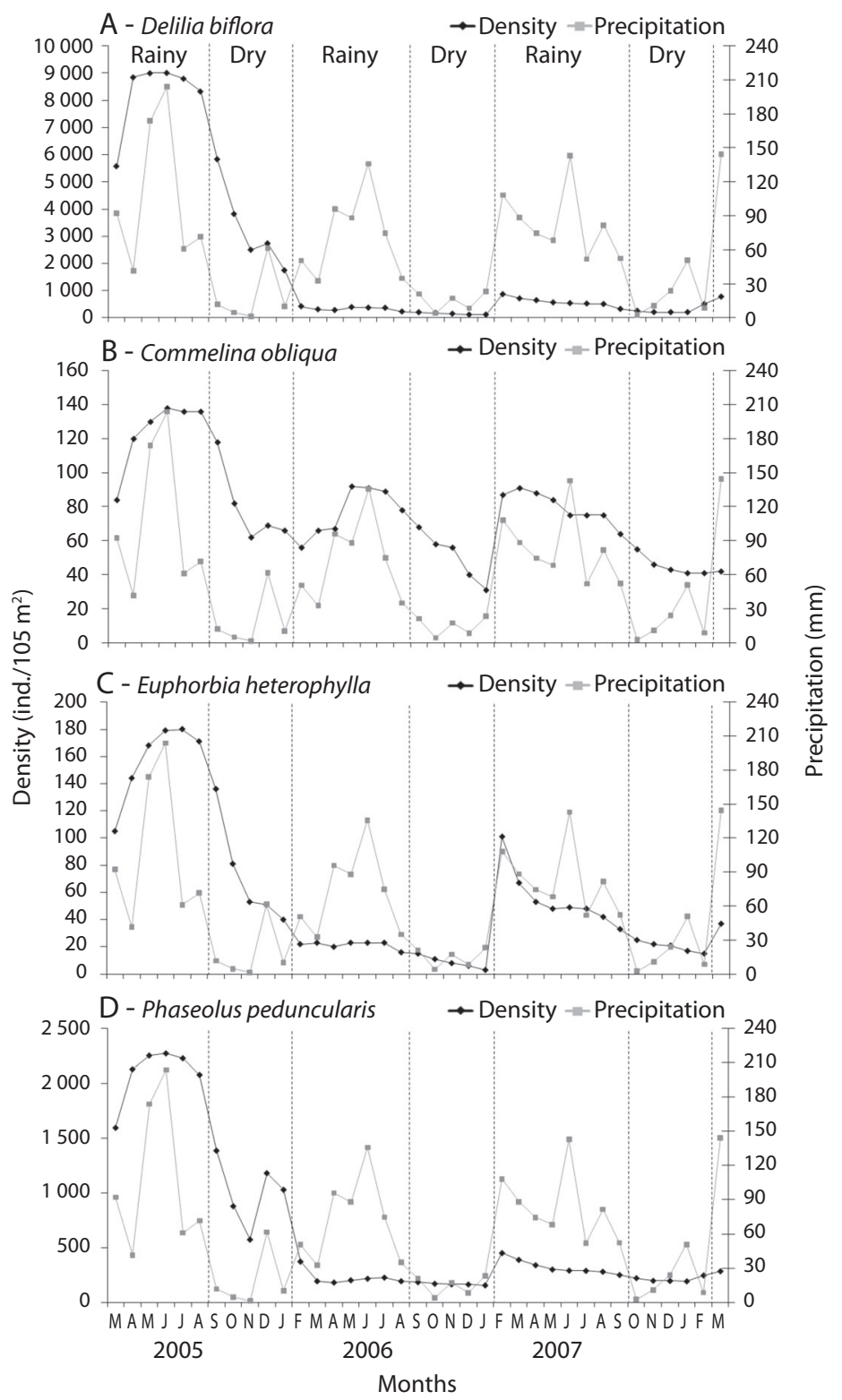

Fig. 3. Monthly densities of the populations of four herbaceous species and precipitation ( $\mathrm{mm}$ ) in a tropical dry forest area (Caatinga) in Northeastern Brazil.

considered therophytes. The GLM analysis showed that the precipitation of current year explained between $3 \%-18 \%$ of the interannual density variation (Table 2). It is noteworthy that the reduction in density between years was less pronounced in the C. obliqua population (Fig. 3; Table 1). The D. biflora, E. heterophylla and $P$. peduncularis populations increased in size from the second to the third period; however, this increase was significant only for E. heterophylla and P. peduncularis (Table 1). On average, the number of C. obliqua individuals was the same in the second and third periods (Table 1). The GLM analysis 
TABLE 2

Results of GLM: Explained variance $\left(\mathrm{R}^{2}\right)$ in density by present and past precipitation $(\mathrm{mm})$

\begin{tabular}{|c|c|c|c|c|c|c|}
\hline Species/Parameters & $\mathrm{DF}$ & SS & MS & $\mathrm{F}$ & $\mathrm{P}$ & $\mathrm{R}^{2}$ \\
\hline \multicolumn{7}{|l|}{ Delilia biflora } \\
\hline Intercept & 1 & 90721724.78 & 90721724.78 & 34.7367 & 0.00000 & \\
\hline Precipitation of year & 1 & 28419684.63 & 28419684.63 & 10.8817 & 0.00233 & 0.0859 \\
\hline Precipitation of previous year & 1 & 214299240.60 & 214299240.60 & 82.0537 & 0.00000 & 0.6479 \\
\hline Error & 33 & 86185983.47 & 2611696.47 & & & \\
\hline \multicolumn{7}{|l|}{ Commelina obliqua } \\
\hline Intercept & 1 & 495.52 & 495.52 & 0.8980 & 0.35020 & \\
\hline Precipitation of year & 1 & 1112.66 & 1112.66 & 2.0164 & 0.16499 & 0.0385 \\
\hline Precipitation of previous year & 1 & 9524.60 & 9524.60 & 17.2610 & 0.00022 & 0.3293 \\
\hline Error & 33 & 18209.41 & 551.80 & & & \\
\hline \multicolumn{7}{|l|}{ Euphorbia heterophylla } \\
\hline Intercept & 1 & 31454.01 & 31454.01 & 27.5189 & 0.00001 & \\
\hline Precipitation of year & 1 & 18864.21 & 18864.21 & 16.5042 & 0.00028 & 0.1831 \\
\hline Precipitation of previous year & 1 & 45773.32 & 45773.32 & 40.0468 & 0.00000 & 0.4442 \\
\hline Error & 33 & 37718.90 & 1143.00 & & & \\
\hline \multicolumn{7}{|l|}{ Phaseolus peduncularis } \\
\hline Intercept & 1 & 5028464.00 & 5028464.00 & 41.4300 & 0.00000 & \\
\hline Precipitation of year & 1 & 1816429.13 & 1816429.13 & 14.9657 & 0.00049 & 0.1003 \\
\hline Precipitation of previous year & 1 & 12173946.32 & 12173946.32 & 100.3024 & 0.00000 & 0.6724 \\
\hline Error & 33 & 4005291.88 & 121372.48 & & & \\
\hline
\end{tabular}

showed that climatic events of the past also had a significant consequence for the four populations. The explanatory power of the precipitation of previous years on the density of populations ranged from $32 \%$ to $67 \%$ (Table 2 ). It is worth mentioning that the precipitation of the previous year had a less pronounced effect on the C. obliqua population (Table 2).

In all periods, the sizes of the four populations were larger during the rainy season and dramatically reduced during the dry season (Fig. 3, Table 1). The four species formed significantly larger populations in the rainy and dry seasons of the first period (Table 1). The D. biflora and E. heterophylla populations had a significant increase in size in the rainy season from the second to the third period (Table 1).

In the D. biflora and P. peduncularis populations, an increase was recorded during an event of climatic anomaly (erratic rain in dry season): in the dry season of the first period (December 2005) and in the dry season of the third period (February 2008). In C. obliqua, there was an increase in the dry season of the first period (December 2005). In P. heterophyl$l a$, there were increases only during the rainy seasons (Fig. 3).

Birth and mortality: For the four species, births were recorded in the rainy and dry seasons in all three periods, except for $P$. heterophylla, which did not recruit any seedlings in the dry season of the second period. In general, all four populations showed peaks of births immediately after the beginning of the rainy season, as observed in the rainy seasons of the first and third periods. In most months of the dry season, the birth rate of the four populations was zero or very close to zero. However, the erratic rains that occurred during the dry seasons (specifically in December 2005 and January 2008) (Fig. 2), were enough to stimulate the recruitment of seedlings. In the four populations, mortality was recorded in the rainy and dry seasons of all three periods, and it was most pronounced in the dry seasons. 


\section{DISCUSSION}

The arid and semiarid environments are characterized by limited and erratic rainfall. Therefore, the variability of annual rainfall provides resource pulses. For example, on rare occasions, when the annual rainfall is much above the average, the higher water availability in the soil favors an exponential increase in the size of populations. Subsequent dry years cause drastic reductions in population size. (Goldberg \& Turner, 1986; Chesson et al., 2004; Villalobos et al., 2013; García-Cháves et al., 2014). In Northeastern Brazilian tropical dry forest areas, studies on the dynamics of caatinga herbaceous plants showed that populations may be dramatically reduced in their density, and may even disappear, from the habitats in drier years (Andrade et al., 2007; Lima et al., 2007; Santos et al., 2007; Silva et al., 2008; Santos et al., 2013b).

In this study, the precipitation of the previous year (2004) was $1064.3 \mathrm{~mm}$ and reduced dramatically to $733.5 \mathrm{~mm}$ in 2005 and $586.5 \mathrm{~mm}$ in 2006. This event of climatic anomaly had a consequence over herbaceous populations demography. The populations size showed great reduction in the driest year. The GLM analysis confirmed that the precipitation of current year explained one part $(3 \%$ - $18 \%$ ) of density reduction (Table 2). It is noteworthy that $C$. obliqua population was the least sensitive to reduction in annual precipitation, because its population size reduction was less pronounced (Table 1). However, the GLM analysis also showed that the explanation power of the climatic events of the past was greater. The precipitation of the previous year explained most of the variation of density $(32 \%$ to $67 \%$ ) (Table 2$)$. Therefore, we showed in this study that events of climatic anomaly (e.g. drastic reduction in precipitation between years) have a strong consequence in the population size of herbaceous species in the present and future time. Thus drastic reduction in total precipitation between years might be a predictive parameter for herbaceous plant population size (in the present and future time) in a Northeastern Brazilian tropical dry forest area (Caatinga), corroborating the hypothesis of this study.

Some species have greater capacity to occupy the space for the regeneration of their populations than others (Miriti et al., 2007; Almazán-Núñez, Arizmendi, \& Eguiart, 2012). Therefore, differences in population size after climatic abnormal events can endure for decades (Miriti et al., 2007). For example, some species reduced about $50 \%$ of the population size in a severe regional drought event and the individuals who survived had reduced growth rate during this episode. A second severe regional drought event, after three years, resulted in the death of individuals who had reduced growth rate leading to a population disappearance (Miriti et al., 2007). In this study, the reduction in population size was so drastic that it is possible that some species do not survive subsequent severe regional drought events. Only long-term monitoring of the populations dynamics will be able to confirm.

Reis et al. (2006) showed that dramatic reductions occured in D. biflora and P. peduncularis populations in drier years, which was confirmed by the present study (Table 1). However, Reis et al. (2006) recorded a moderate increase in the size of the $C$. obliqua population in drier years, a trend opposite to that found in our research. According with this study C. obli$q u a$ was less sensitive to reduction of annual precipitation. In the third period, which was a rainier one, the increase in $P$. peduncularis, $E$. heterophylla and D. biflora population sizes indicated that the density of plants of those species was related most strongly to the degree of rainfall increase between years (Table 1). $C$. obliqua maintained the same number of individuals from the second to the third period (Table 1). This shows that the response of $C$. obliqua to annual rainfall variation is slower than that of the other herbaceous plants studied. In addition, despite the climatic seasonality leading to a dramatic reduction in population density in dry periods, the response of populations may vary with time. Also, there is probably a secondary factor (e.g. microhabitats) 
attenuating the influence of climate seasonality on the size of herbaceous populations. For example, variations in the availability of nutrients and water content in the soil on a small scale, form microhabitats that harbor herbaceous populations more numerous (Haskell, Flaspohler, Webster, \& Meyer, 2010; Dahwa et al., 2013). Although we have not quantified the soil properties in this study, it is possible that they can mitigate the effect of temporal variation in precipitation and contribute to the maintenance of some herbaceous populations of the caatinga. Therefore, future studies are needed to test this hypothesis.

In dry (Mondragón, Durán, Ramírez, \& Valverde, 2004; Vega \& Montaña, 2004; Volis et al., 2004; Wang, 2005; Nippert et al., 2006 and humid (Zotz, 1998; Castellani, Scherer, \& Paula, 2001; Nordbakken, Rydgren, \& Okland, 2004; Noel, Porcher, Moret, \& Machon, 2005) areas of the world, the birth of herbaceous plants is concentrated in the periods of water availability. In the present study, the birth rates recorded for the four populations during the rainy season, followed the pattern found for several vegetation types in Brazil and in the world. Water shortage is the main factor responsible for the mortality of herbaceous plants in dry (Mondragón et al., 2004; Volis et al., 2004; Nippert et al., 2006; Santos et al., 2007; Silva et al., 2008) and humid (Zotz, 1998; Castellani et al., 2001; Nordbakken et al., 2004; Vilà, Bartolomeus, Gimeno, Traveset, \& Moragues, 2006) forest areas during dry seasons; however, herbivory (Maron, \& Crone, 2006; Gotelli, 2007), intraspecific competition (Suzuki, Kudoh, \& Kachi, 2003; Volis et al., 2004) and interspecific competition (Miller \& Duncan, 2003; Nordbakken et al., 2004; Thomson, 2005) have been identified as the main causes of mortality during the rainy season.

There is evidence that sporadic or erratic rain occurring during the dry season may induce seed germination; however, the chance of survival of a seedling recruited during the dry season is low and individuals may die before reaching the reproductive stage (Salo, 2004; Araújo, 2005; Araújo et al., 2007; Lima et al., 2007). Such a fact was confirmed in this study, because the birth peaks of the dry season reflected the disruptive effect of rainfall peaks occurring in that season, showing that erratic rainfall may mask the role of climate seasonality on population dynamics in dry environments.

This study showed that the events of climatic anomaly (e.g. the 2006 drought and erratic rain in dry season) has a strong impact on the demography of herbaceous populations in current year and this impact is extended for subsequent years, corroborating the hypothesis of this study. However, the effect of events of climatic anomaly can be less pronounced in some species, as recorded in this study for $C$. obliqua. While D. biflora, E. heterophylla and $P$. peduncularis population sizes decreased by $96 \%, 86 \%$ and $87 \%$, respectively, C. obliqua decreased only $35 \%$ (Table 1 ). This leads us to consider the following hypothetical model: in tropical dry forest area, herbaceous populations may respond to inter-annual variation in precipitation of the past and present in three ways: 1) the most sensitive species reduces dramatically the population size; 2) the less sensitive species reduces moderately the population size; 3 ) variations in the population size of species further adapted are not explained by past and/ or present precipitation. Therefore, it is necessary further studies to test the hypothetical model and identify the species group of each of the three responses and identify the adaptive strategies of each species. This information can be useful to propose management strategies, conservation and restoration of degraded areas.

\section{ACKNOWLEDGMENTS}

The authors would like to thank the CNPq for the financial support $(478521 / 2001-4$; 478087/2004-7; 471805/2007-6; 301147/20033 ; 303544/2007-4) and for the granting of a doctoral fellowship; the experimental station of the Pernambuco Agronomic Institute (IPA) and the Rural Federal University of Pernambuco (UFRPE) for their logistic support; Andre Santos for support in statistical analysis; and the 
researchers at the Vegetal Ecology of Natural Ecosystems Laboratory (LEVEN-UFRPE) for their help in data collection and processing.

\section{RESUMEN}

Efecto de la variación temporal de la precipitación sobre la demografía de cuatro poblaciones herbáceas en una área de bosque tropical seco en el Noreste del Brasil. En los bosques tropicales secos, la dinámica de las poblaciones herbáceas están fuertemente influenciadas por la variación estacional y anual de la precipitación total. Por otra parte, los acontecimientos presentes y pasados de anomalía climática (por ejemplo, años de sequía y lluvia errática antes de la temporada de crecimiento) pueden causar reducciones drásticas de tamaño de la población, lo que lleva a la desaparición temporal de algunas especies. Por lo tanto, este estudio tiene como objetivo evaluar, durante três años, la dinámica de Delilia biflora (Asteraceae), Commelina obliqua (Commelinaceae), Phaseolus peduncularis (Fabaceae) y Euphorbia heterophylla (Euphorbiaceae). El estudio se realizó en una zona de bosque seco tropical conocida como Caatinga, situado en la estación experimental del Instituto Agronómico de Pernambuco (IPA), en Caruaru, Pernambuco, Brasil. La Caatinga tiene un clima semiárido y fuerte variación estacional y anual de la precipitación total. Durante este estudio, hubo un evento de anomalía climática llamado la sequía de 2006 y la lluvia errática en la estación seca. El nacimiento, la muerte y la supervivencia fueron monitoreados mensualmente en 105 parcelas de $1 \times 1 \mathrm{~m}$. Las diferencias en densidad entre años y estaciones se evaluaron mediante la prueba de Kruskal-Wallis. El poder explicativo de la precipitación del presente y del pasado sobre la densidad se evaluó utilizando el Modelo Lineal Generalizado. En este estudio, fue el primer registro de Euphorbia heterophylla en el área de estudio. Las poblaciones estudiadas fueron mayores en los años más húmedos y durante la temporada de lluvias, y se redujeron drásticamente en el año más seco y en las estaciones secas. Commelina obliqua fue la menos sensible a la variación de la precipitación total. Con respecto a la densidad, las cuatro especies estuvieron presentes durante los tres años. Las tasas de natalidad fueron mayores durante la temporada de lluvias y las tasas de mortalidad fueron mayores en la estación seca. Lluvias esporádicas en la estación seca causado pronunciado reclutamiento de plántulas seguida de muerte y tuvo un fuerte impacto en la dinámica de D. biflora, E. heterophylla y P. peduncularis. La precipitación del año en curso explica entre el $3 \%$ y $18 \%$ de la variación interanual de la densidad y el poder explicativo de la precipitación del año anterior en la densidad de las poblaciones varió de $32 \%$ a $67 \%$. Por lo tanto, los fenómenos climáticos del pasado también tienen una consecuencia significativa para las cuatro poblaciones. En conclusión, la drástica reducción de la precipitación total entre años podría ser un parámetro predictivo para el tamaño de la población de plantas herbáceas (en el momento presente y futuro) en una área de bosque tropical seco en el Noreste brasileño.

Palabras clave: Caatinga, densidad, dinámica, lluvia, reclutamiento de plántulas, semiárido.

\section{REFERENCES}

Alcoforado-Filho, F. G., Sampaio, E. V. S. B., \& Rodal, M. J. N. (2003). Florística e fitossociologia de um remanescente de vegetação caducifólia espinhosa arbórea em Caruaru. Acta Botanica Brasilica, 17, 287-303.

Almazán-Núñez, R. C., Arizmendi, M. D. C., \& Eguiart, P. C. (2012). Changes in composition, diversity and structure of woody plants in successional stages of tropical dry forest in southwest Mexico. Revista Mexicana de Biodiversidad, 83, 1096-2010.

Andrade, J. R., Santos, J. M. F. F., Lima, E. M., Lopes, C. G. R., Silva, K. A., \& Araújo, E. L. (2007). Estudo populacional de Panicum trichoides Swart. (Poaceae) em uma área de Caatinga em Caruaru, Pernambuco. Revista Brasileira de Biociências, 5, 858-860.

Araújo, E. L. (2005). Estresses abióticos e bióticos como forças modeladoras da dinâmica de populações vegetais da Caatinga. In R. J. M. C. Nogueira, E. L. Araújo, L. G. Willadino, \& U. M. T. Cavalcante (Eds.), Estresses ambientais: danos e beneficios em plantas (pp. 50-64). Recife, Brazil: MXM Gráfica e Editora.

Araújo, E. L., Castro, C. C., \& Albuquerque, U. P. (2007). Dynamics of Brazilian Caatinga - a review concerning the plants, environment and people. Functional Ecology and Communities, 1, 15-28.

Araújo, E. L., Silva, K. A., Ferraz, E. M. N., Sampaio, E. V. S. B., \& Silva, S. I. (2005). Diversidade de herbáceas em microhabitats rochoso, plano e ciliar em uma área de Caatinga, Caruaru- PE. Acta Botanica Brasilica, 19, 285-294.

Ayres, M., Ayres-júnior, M., Ayres, D. L., \& Santos, A. A. S. (2007). BioEstat - Aplicações estatísticas nas áreas das ciências bio-médicas. Belém: Ong Mamiraua.

Belsky, A. J. (1990). Tree/grass ratios in East African savannas: a comparison of existing models. Journal of Biogeography, 17, 483-489.

Castellani, T. T., Scherer, K. Z., \& Paula, G. S. (2001). Population ecology of Paepalanthus polyanthus (Bong) Kunth: Demography and life history of a sand dune monocarpic plant. Revista Brasileira de Botânica, 24, 123-124.

Chesson, P., Gebauer, R. L. E., Schwinning, S., Huntly, N., Wiegand, K., Ernest, M. S. K., ... Weltzin, J. F. (2004). Resource pulses, species interactions, and 
diversity maintenance in arid and semi-arid environments. Oecologia, 141, 236-253.

Condit, R., Hubbell, S., \& Foster, R. B. (1996). Changes in tree species abundance in a neotropical forest: impact of climate change. Journal of Tropical Ecology, 12, 231-256.

Dahwa, E., Mudzengi, C. P., Hungwe, T., Shoko, M. D., Poshiwa, X., Kativu, S., \& Murungweni, C. (2013). Influence of grazing intensity on soil properties and shaping herbaceous plant communities in semi-arid dambo wetlands of Zimbabwe. Journal of Environmental Protection, 4, 1181-1188.

García-Cháves, J. H., Montaña, C., Perroni, Y., Sosa, V. J., \& García-Licona, J. B. (2014). The relative importance of solar radiation and soil origin in cactos seedling survivorship at two spatial scales: plant association and microhabitat. Journal of Vegetation Science, 25, 668-680.

Goldberg, B. E., \& Turner, R. M. (1986). Vegetation change and plant demography in permanent plots in the sonoran desert. Ecology, 67(3), 695-712.

Gotelli, N. J. (2007). Ecologia. Londrina: Editora Planta.

Haskell, D. E., Flaspohler, D. J., Webster, C. R., \& Meyer, M. W. (2010). Variation in soil temperature, moisture, and plant growth with the addition of downed woody material on lakeshore restoration sites. Restoration Ecology, 20(1), 113-121.

Khurana, E., \& Singh, J. S. (2001). Ecology of seed and seedling growth for conservation and restoration of tropical dry forest: a review. Environmental Conservation, 28, 39-52.

Lima, E. M., Araújo, E. L., Ferraz, E. M. N., Sampaio, E. V. S. B., Silva, K. A., \& Pimentel, R. M. M. (2007). Fenologia e dinâmica de duas populações herbáceas da Caatinga. Revista de Geografia, 24, 124-141.

Lucena, R. F. P., Nascimento, V. T., Araújo, E. L., \& Albuquerque, U. P. (2008). Local uses of native plants in an area of Caatinga vegetation (Pernambuco, NEBrazil). Ethnobotany Research and Applications, 6, 1-3.

Maron, J. L., \& Crone, E. (2006). Herbivory: effects on plant abundance, distribution and population growth. Proceedings of the Royal Society, 273, 2575-2584.

Miller, A., \& Duncan, R. (2003). Extrinsic and intrinsic controls on the distribution of the critically endangered cress, Ischnocarpus exilis (Brassicaceae). Biological Conservation, 110, 153-60.

Miriti, M. N., Rodríguez-Buritica, S., Wright, S. J., \& Howe, H. (2007). Episodic death across species of desert shrubs. Ecology, 88(1), 32-36.

Mondragón, D., Durán, R., Ramírez, I., \& Valverde, T. (2004). Temporal variation in the demography of the clonal epiphyte Tillandsia brachycaulos
(Bromeliaceae) in the Yucatán Peninsula, Mexico. Journal of Tropical Ecology, 20, 189-200.

Monteiro, J. M., Lins Neto, E. M. N., Araújo, E. L., Amorim, E. L. C., \& Albuquerque, U. P. (2011). Bark regeneration and tannin content in Myracrodruon urundeuva Allemão after simulation of extractive damages-implications to management. Environmental Monitoring and Assessment, 180, 31-39.

Mori, A. S., Silva, L. A. M., \& Lisboa, G. (1989). Manual de manejo do herbário fanerogâmico. Ilhéus: Centro de Pesquisa do Cacau.

Nippert, J. B., Knapp, A. K., \& Briggs, J. M. (2006). Intraannual rainfall variability and grassland productivity: can the past predict the future? Plant Ecology, 184, 65-74.

Noel, F., Porcher, E., Moret, J., \& Machon, N. (2005). Connectivity, habitat heterogeneity, and population persistence in Ranunculus nodiflorus, an endangered species in France. New Phytologist, 169, 71-84.

Nordbakken, J. F., Rydgren. K., \& Okland, R. H. (2004). Demography and population dynamics of Drosera angelica and D. rotundifolia. Journal of Ecology, 92, 110-121.

Prado, D. (2003). As Caatingas da América do Sul. In I. R. Leal, M. Tabarelli, \& J. M. C. Silva (Eds.), Ecologia e conservação da Caatinga (pp. 3-73). Recife, Brazil: Editora Universitária.

Reis, A. M., Araújo, E. L., Ferraz, E. M. N., \& Moura, A. N. (2006). Inter-annual variations in the floristic and population structure of an herbaceous community of "Caatinga" vegetation in Pernambuco, Brazil. Revista Brasileira de Botânica, 29, 497-508.

Salo, L. F. (2004). Population dynamics of red brome (Bromus madritensis subsp. rubens): times for concern, opportunities for management. Journal of Arid Environments, 57, 291-296.

Sampaio, E. V. S. B. (1995). Overview of the Brazilian Caatinga. In S. Bullock, H. A. Mooney, \& E. Medina (Eds.), Seasonally dry tropical forests (pp. 35-63). Cambridge: United Kingdom: Cambridge University Press.

Santos, D. M., Silva, K. A., Albuquerque, U. P., Santos, J. M. F. F., Lopes, C. G. R., \& Araújo, E. L. (2013a). Can spatial variation and inter-annual variation in precipitation explain the seed density and species richness of the germinable soil seed bank in a tropical dry forest in Northeastern Brazil? Flora (Jena), 208, 445-452.

Santos, J. M. F. F., Andrade, J. R., Lima, E. M., Silva, K. A., \& Araújo, E. L. (2007). Dinâmica populacional de uma espécie herbácea em uma área de floresta tropical seca na Nordeste do Brasil. Revista Brasileira de Biociências, 5, 855-857. 
Santos, J. M. F. F., Santos, D. M., Lopes, C. G. R., Silva, K. A., Sampaio, E. V. S. B., \& Araújo, E. L. (2013b). Natural regeneration of the herbaceous community in a semiarid region in Northeastern Brazil. Environmental Monitoring and Assessment, 185, 8287-8302.

Silva, K. A., Lima, E. M., Santos, J. M. F. F., Andrade, J. R., Santos, D. M., Sampaio, E. V. S. B., \& Araújo, E. L. (2008). Dinâmica de gramíneas em uma área de Caatinga de Pernambuco-Brasil. In A. N. Moura, E. L. Araújo, \& U. P. Albuquerque (Eds.), Biodiversidade, potencial econômico e processos eco-fisiológicos em ecossistemas nordestinos (pp. 39-64). Recife, Brazil: Comunigraf.

Suzuki, Z. O., Kudoh, H., \& Kachi, N. (2003). Spatial and temporal variations in mortality of the biennial plant, Lysimachia rubida: effects of intraspecific competition and environmental heterogeneity. Journal of Ecology, 91, 114-125.

Swaine, M. D., \& Lieberman, D. (1987). Note on the calculation of mortality rates. Journal of Tropical Ecology, 3, 2-3.

Thomson, D. (2005). Measuring the effects of invasive species on the demography of a rare endemic plant. Biological Invasions, 7, 615-624.

Vega, E., \& Montaña, C. (2004). Spatio-temporal variation in the demography of a bunch grass in a patchy semiarid environment. Plant Ecology, 175, 107-120.
Vieira, D. L. M., \& Scariot, A. (2006). Principles of natural regeneration of tropical dry forests for regeneration. Restoration Ecology, 14, 11-20.

Vilà, M., Bartolomeus, I., Gimeno, I., Traveset, A., \& Moragues, E. (2006). Demography of the invasive geophyte Oxalis pes-caprae across a Mediterranean Island. Annals of Botany, 97, 1055-1062.

Villalobos, S. M., Poorter, L., \& Martínez-Ramos, M. (2013). Effects of ENSO and Temporal Rainfall Variation on the Dynamics of Successional Communities in Old-Field Succession of a Tropical Dry Forest. Plos One, 8(12), 1-12.

Volis, S., Mendlinger, S., \& Ward, D. (2004). Demography and role of the seed bank in Mediterranean and desert populations of wild barley. Basic and Applied Ecology, 5, 53-64.

Wang, R. Z. (2005). Demographic variation and biomass allocation of Agropyron cristatum grown on steppe and dune sites in the Hunshandake Desert, North China. Grass and Forage Science, 60, 99-102.

Zar, J. H. (1996). Biostatistical analysis. New Jersey: Prentice Hall.

Zotz, G. (1998). Demography of the epiphytic orchid, Dimerandra emarginata. Journal of Tropical Ecology, 14, 725-741. 